\title{
Detection of Vibrio Pathogens from Cultured Turbot (Scophthalmus maximus) by Loop-Mediated Isothermal Amplification (LAMP)
}

\author{
Phares Choto, Fedrick Charles, Blessing Gwekwe, Yingjie Li, Jamal S Akida, Meiling Chen, Wenhua \\ Miao, Huimin Lin, Shan SM H, Cheng Luo* and Shanggui Deng* \\ College of Food and Pharmacy, Zhejiang Ocean University, China
}

\begin{abstract}
Vibrio species are the major concern to the aquaculture industry because they are both fish pathogens and also bring foodborne diseases to human. Loop-mediated isothermal amplification (LAMP) is a simple and rapid method to detect the pathogens. In this study, we developed a specific and sensitive loop-mediated isothermal amplification (LAMP) assay to detect Vibrio scophthalmi, a pathogen of turbot. 16s rDNA of Vibrio scophthalmi was used as the template to design a set of specific LAMP primers. The LAMP primers were designed, according to our requirements, by Beijing Lanpu Bio-tech Co. Ltd. using Primer Explorer V4 software (http://primerexplorer.jp/e/v4_manual/index.html). The DNA of intestinal pathogens of turbot was extracted using proteinase $\mathrm{K}$ kit (Beyotime). By initial trial at $64{ }^{\circ} \mathrm{C}$ of water bath the reaction become visible in turbid or in fluorescent color after $20 \mathrm{~min}$. Three different turbot fish were positive, indicating that they were containing Vibrio scophthalmi in their intestine and this signifies that all the primers bind specifically to the gene of $16 \mathrm{~S}$ rRNA gene, in another word they are pathogen positive. To confirm the specific amplification of the 16S rRNA gene, gel electrophoresis was run. The resulted bands were specific to the region of 16SrRNA gene supposed to be amplified. The lowest detection limit of the LAMP assay was the DNA concentration of $1.25 \times 10^{-17} \mathrm{\mu g} / \mathrm{ml}$. This LAMP method can be of high value to the food industry due to its various advantages such as speed, specificity, sensitivity, cost- and labor-efficiency.
\end{abstract}

\section{Introduction}

Fish has been the largest traded food commodity, supported by the growth in aquaculture, which has been the fastest growing food production sector over the past 20 years [1]. Fish is usually low in saturated fats, carbohydrates, and cholesterol and provides not only high-value protein but also a wide range of essential micronutrients, including various vitamins, minerals, and polyunsaturated omega-3 fatty acids [2]. Increases in the amount of fish produced by aquaculture pushed global fish production to an all-time high of about 171 million tonnes in 2016, according to a new report by the United Nations Food and Agriculture Organization (FAO). Aquaculture represented $47 \%$ of the total and $53 \%$ if non-food uses (including a reduction to fishmeal and fish oil) are excluded [1].

However, a major impediment in the aquaculture industry is the abrupt eruption of diseases, especially those caused by Vibrio spp. Vibrio species are ubiquitous in aquatic ecosystems causing various infections in fish, crustacean, and shellfish [3]. Vibrio anguillarum, V. salmonicida, V. ordalii, V. vulnificus, $V$. harveyi and $V$. scophthalmi are among the pathogens that lead to the biggest losses in aquaculture all over the world [4]. Some of the Vibrio spp. are potential zoonotic to human, causing risk of zoonosis in aquaculture farmers and in consumers of aquaculture products [4]. V. scophthalmi is the common pathogen of turbot residing in the alimentary canal of the fish [5]. Therefore, effective testing of fish in aquaculture for the presence of Vibrio is important.

Conventional microbiological methods for the detection of Vibrio from aquaculture take about five days which is time-consuming, labor extensive and costly [6]. In spite of many quick molecular methods such as DNA microarrays, conventional PCR, real-time PCR and immunoassay have been developed and used for detection of vibrio from aquaculture a rapid

*Corresponding author: Cheng Luo and Shanggui Deng, College of Food and Pharmacy, Zhejiang Ocean University, No.1 Haida South Road, Changzhi Island, Lingcheng New District, Zhoushan 316022, China

Accepted: February 29, 2020

Published online: March 02, 2020

Citation: Choto P, Charles F, Gwekwe B, et al. (2020) Detection of Vibrio Pathogens from Cultured Turbot (Scophthalmus maximus) by Loop-Mediated Isothermal Amplification (LAMP). J Mar Biol Aquaculture Res 3(1):25-29 
Citation: Choto P, Charles F, Gwekwe B, et al. (2020) Detection of Vibrio Pathogens from Cultured Turbot (Scophthalmus maximus) by LoopMediated Isothermal Amplification (LAMP). J Mar Biol Aquaculture Res 3(1):25-29

and inexpensive technology is always most preferred. LAMP" which stands for Loop-mediated Isothermal Amplification is a simple, rapid, specific and cost-effective nucleic acid amplification method solely developed by Eiken Chemical Co., Ltd. It uses four different primers specifically designed to recognize six distinct regions on the target gene and the reaction process proceeds at a constant temperature using strand displacement reaction. Amplification and detection of a gene can be completed in a single step, by incubating the mixture of samples, primers, DNA polymerase with strand displacement activity and substrates at a constant temperature (about 65 $\left.{ }^{\circ} \mathrm{C}\right)$. It provides high amplification efficiency, with DNA being amplified 109-1010 times in 15-60 minutes. Because of its high specificity, the presence of amplified product can indicate the presence of the target gene [7]. In this study, we developed a LAMP assay targeting the 16SrRNA gene to detect Vibrio scophthalmi from the intestine of turbot fish in aquaculture. The 16SrRNA gene codes for the RNA component of the 30 subunit of the bacterial ribosome. It is widely present in all prokaryotic cells. 16SrRNA genes have conserved and variable regions, where conserved areas reflect phylogenetic relationship among species (and are used as a site for PCR priming) and highly variable regions reflecting differences between species [8]. The objectives of this study were 1) to develop a new LAMP method for the detection of Vibrio spp. from aquaculture using Vibrio scophthalmi pathogen of turbot as a model study, and 2) to evaluate the sensitivity of the LAMP method in detection of the pathogen.

\section{Material and Methods}

\section{Sample preparation}

Three turbot fish were bought from East River market in Zhoushan. Fish were eviscerated to get intestine for DNA extraction of Vibrio scophthalmi. The intestine was used for DNA extraction of pathogen because in the gastrointestinal tract is where the pathogen normally resides. From three fish three sample were obtained sample $A$, sample $B$, and sample C.

\section{DNA extraction}

DNA templates used in this study were prepared using DNA extraction kit from Beyotime (D0063). $1 \mathrm{ml}$ of $\mathrm{dd}_{2} \mathrm{O}$ was added into $1 \mathrm{~g}$ of the fish intestine and then minced using puree machine to obtain a puree. $100 \mu$ of puree obtained was taken into an extraction tube, then $30 \mu \mathrm{l}$ of proteinase $\mathrm{K}$ was added and the mixture was incubated at $55^{\circ} \mathrm{C}$ for 1 hour. After 1 hour of incubation, $300 \mu$ of lysis buffer B was added in the mixture, the mixture was vortex and incubated at 700 ${ }^{\circ} \mathrm{C}$ for 10 minutes. Then, $200 \mu$ of ethanol was added, vortex and loaded into the mini-column. In the mini-column $500 \mu \mathrm{l}$ of washing bufferl was added and spun for 1 minute, followed with the addition of $500 \mu \mathrm{l}$ of washing buffer II and spun for 1 minute. The mini-column was assembled in Eppendorf tube and $200 \mu$ of elution buffer was added and incubated for 5 minutes at room temperature and spun down for 1 minute and then the DNA solution was collected in the bottom of Ep-

Table 1: The set of primers designed and used in the LAMP assay.

\begin{tabular}{|l|l|l|}
\hline Primers & Types & Sequence $\left(\mathbf{5}^{\prime}\right.$ to $\mathbf{3}^{\prime} \mathbf{)}$ Length $(\mathbf{b p})$ \\
\hline Vs-F3-3 & Forward outer & TGGAGCATCGGTAGTGCC 18 \\
\hline Vs-B3-3 & Backward outer & CATCACCCACGTAGAAAGAGG 21 \\
\hline Vs-FIP-3 & Forward inner & GAGTCTGCGCCGTAATCCCAGATGGTGTCGGTTTTAGTGTCC 42 \\
\hline Vs-BIP-3 & Backward inner & TAACCCGTATTGGCTCAGAGCTGTGGGCCGATACCTAAATTGC 43 \\
\hline Vs-LB-3 & Loop primer & ACATCCAACCCAATCACCGTC 21 \\
\hline
\end{tabular}

Table 2: Development of LAMP assay.

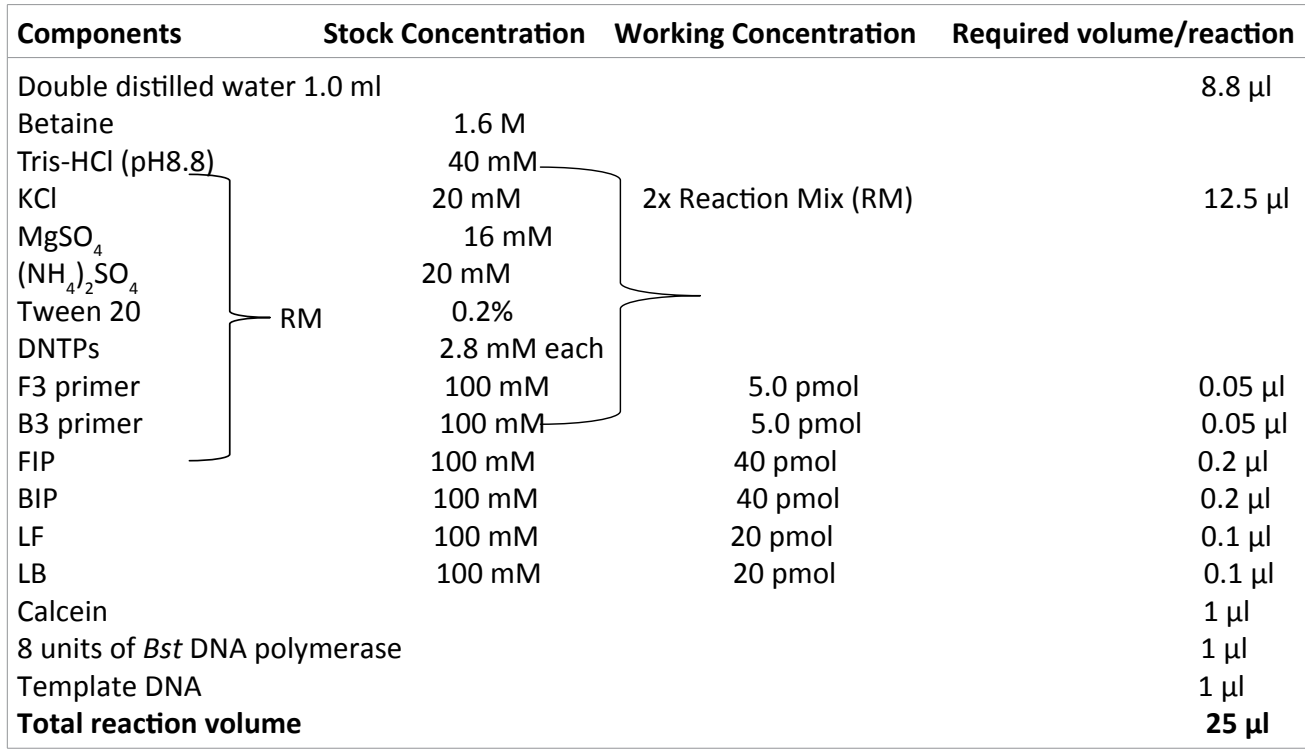


Citation: Choto P, Charles F, Gwekwe B, et al. (2020) Detection of Vibrio Pathogens from Cultured Turbot (Scophthalmus maximus) by LoopMediated Isothermal Amplification (LAMP). J Mar Biol Aquaculture Res 3(1):25-29

pendorf tube. The tubes were labeled and stored at $-20^{\circ} \mathrm{C}$ for LAMP experiment.

\section{Design of LAMP primer}

The primers set were designed by Beijing Lanpu Bio-tech Co. Ltd. using the $16 \mathrm{~S}$ rRNA gene sequence of Vibrio scophthalmi (GenBank: NR_025992) using Primer Explorer V4 software (http://primerexplorer.jp/e/v4_manual/index.html). The set primers consisted of five primers, four of them targeting 6 regions on the specific gene: a forward inner primer (FIP), a backward outer primer (BIF) and two outer primers (F3 and B3), and the last five is the loop primer either LB. All primers were assessed for specificity before use in LAMP assays by doing a BLAST search with sequences in GenBank (https:// www.ncbi.nlm.nih.gov/guide/howto/design-pcr-primers/) (Table 1).

\section{Development of LAMP assay}

The following reagents were used in the LAMP assay; primers, betaine, Tween 20, dNTPs, Tris- $\mathrm{HCl}$ (pH 8.8), KCL, $\mathrm{MgSO}_{4},\left(\mathrm{NH}_{4}\right)_{2} \mathrm{SO}_{4}$ and Bst DNA polymerase, Distilled Water. LAMP products in the tube were visualized by adding $1 \mu \mathrm{L}$ of the Loopamp ${ }^{\circledR}$ Florescent Detection Reagent, (Table 2) after the repeated Optimizations, whereby the amplification was carried out between $60^{\circ} \mathrm{C}$ and $65^{\circ} \mathrm{C}$ for $60 \mathrm{~min}$ and at $64^{\circ} \mathrm{C}$ for $30 \mathrm{~min}, 45 \mathrm{~min}, 60 \mathrm{~min}, 70 \mathrm{~min}, 80 \mathrm{~min}$ and $90 \mathrm{~min}$, and was then stopped by heating at $80^{\circ} \mathrm{C}$ for $5 \mathrm{~min}$.

\section{Gel electrophoresis}

Gel electrophoresis was performed to confirm the presence of amplicons. $2 \%$ of agarose gel concentration was used, Trans 2K Plus DNA Mark was used as a DNA ladder and Ethidium Bromide was used as gel dye. The process was run at a constant voltage of $100 \mathrm{~V}$ for 90 minutes and the bands were visualized at UV-light.

\section{Sensitivity test}

The sensitivity of the LAMP method on detecting and amplifying the target gene was performed first by determining the initial concentration of the template DNA. This was done by spectrophotometer method on which the sample was diluted by a factor of 100 and measured at a wavelength of 260 $\mathrm{nm}$ and $280 \mathrm{~nm}$ and the mean ratio of the two absorbance reading $\mathrm{OD}_{260} / \mathrm{OD}_{280}$ was used to calculate the concentration of DNA using the following formula;

\section{DNA concentration $(n g / \mu l)=O D_{260} / O D_{280} * 50 \mathrm{ng} / \mu \mathrm{l} * \mathrm{di}-$ lution factor}

Initial concentration was serially diluted up to the factor of $10^{16}$ then LAMP experiment was performed.

\section{Results}

\section{Development of LAMP assay}

Optimal conditions for detection of '16s rDNA' using the LAMP: The LAMP assay was carried out using 16s rDNA as the template to optimize the reaction temperature and time used. After optimization, LAMP was performed in a final volume of $25 \mu$ l containing $8 \mathrm{U}$ Bst DNA polymerase (large

\section{$\begin{array}{lllll}1 & 2 & 3 & \mathbf{P} & \mathbf{N}\end{array}$}

A

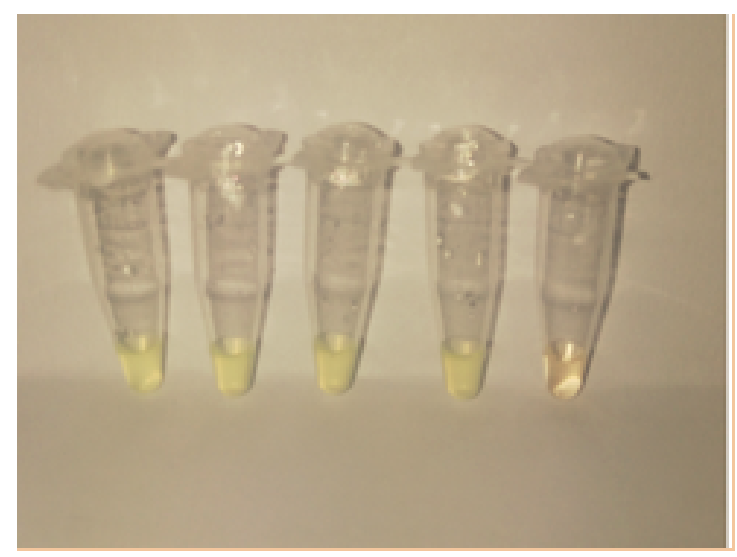

B

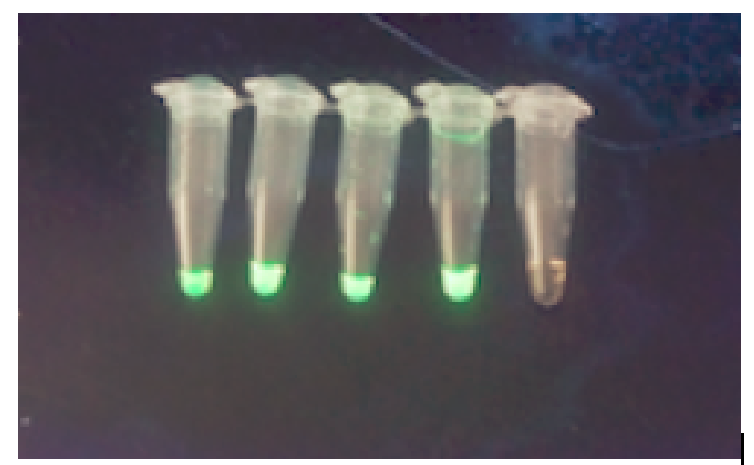

C

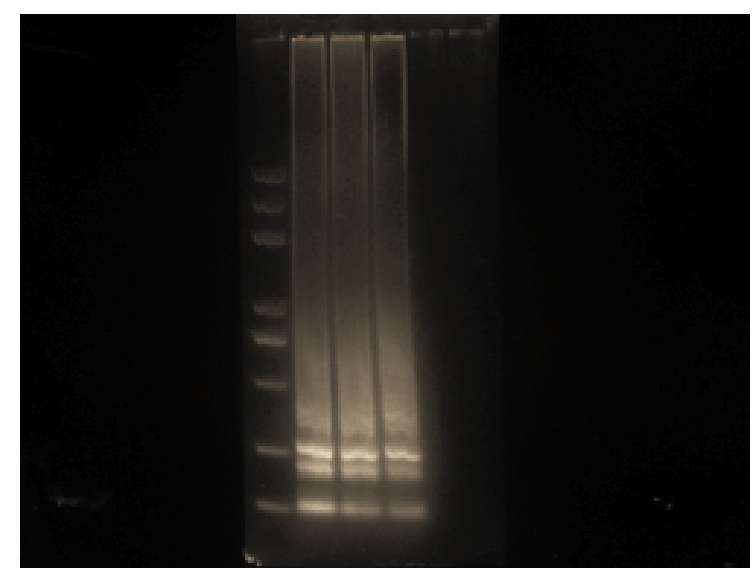

Figure 1: Loop-mediated isothermal amplification procedure (LAMP) amplification and detection of vibriospecies "Vibrio scophthalmi "using (GenBank; NR_025992) primer sets. Lane 1) First turbot fish; 2) Second turbot fish; 3) Third turbot fish; P, Positive control DNA $(6,557$ bp of lambda phage plasmid DNA digested by Hind III); and $N$, negative control (no DNA). Visualization $A$, under normal light, $B$, under UV light and C, with ethidium bromide staining on a $2 \%$ agarose gel; Trans $2 \mathrm{~K}$ Plus DNA ladder appears in the first lane.

fragment; Beijing Lanpu Bio-tech Co. Ltd.), 40.0 pmol each of FIP and BIP, 5.0 pmol each of F3 and B3 primers, 20 pmol of loop primer, $1.0 \mu \mathrm{l}$ of DNA extraction, $12.5 \mu \mathrm{l}$ Isothermal Master Mix and $1.0 \mu \mathrm{l}$ of calcein for fluorescence detection. The LAMP assay was conducted under Optimal Temperature and time, $64{ }^{\circ} \mathrm{C}$ for $60 \mathrm{~min}$ followed by a heating at $80^{\circ} \mathrm{C}$ for $5 \mathrm{~min}$ to stop the reaction. The reaction was conducted in the water bath. 
Citation: Choto P, Charles F, Gwekwe B, et al. (2020) Detection of Vibrio Pathogens from Cultured Turbot (Scophthalmus maximus) by LoopMediated Isothermal Amplification (LAMP). J Mar Biol Aquaculture Res 3(1):25-29

Visual detection of LAMP products: Numerous methods for visual detection of LAMP products were assessed. These included direct observation of solution turbidity in the reaction tube, Visualization of the formation of the green fluorescent under UV light and gel electrophoresis (Figure 1). The formation of magnesium pyrophosphate precipitate during the synthesis of DNA facilitated detection of positive amplification directly in the reaction tubes (Figure 1). The precipitate was clearly observed under UV light, where it appeared as a bright green fluorescence, Calcein produced a green fluorescence during DNA synthesis, which was more apparent under UV light (Figure 1). The LAMP products subjected to electrophoresis showed three bands (Figure 1). The consequent LAMP assay found that all three DNA Sample from turbot fishes could be amplified and visualized using calcein under UV light or electrophoresis (Figure 1). No detectable level of precipitate formed in the negative reactions and the solution appeared pale yellow.

\section{Sensitivity of the LAMP assay}

To determine the sensitivity of the LAMP assay, DNA templates of three turbot fishes were tested by the LAMP. By using a series of dilutions of $10^{1}$ to $10^{16}$ copies of DNA from 1.25 $\times 10^{-3} \mu \mathrm{g} / \mathrm{ml}$ as the Initial DNA Concentration of turbot fish number 3 . The results revealed a reproducible positive amplification for a tested sample, where by a Concentration of 1.25 $\times 10^{-17} \mu \mathrm{g} / \mathrm{ml}$ was recorded in tube number 14 as the lowest Concentration to be amplified. The presence of a LAMP product was determined under UV light.

\section{Discussion}

Precise pathogen detection of Vibrio scophthalmi in turbot Fish is fundamental for the management of diseases such as foodborne diseases to human which can be transmitted by consuming unwell cooked fishes. Though pathogen screening tests are already in place for the detections and management of diseases, these remain as a big challenge for many scientists and researches due to expensive Equipment (e.g., require thermal cycling equipment), labor extensive and time consuming (require long amplification times and post-PCR analysis via gel electrophoresis or qPCR software). One of the best promising new rapid methods for detection of Vibrio scophthalmi is LAMP, which has been used successfully for medical diagnostics and research activities for detection of Pathogen in Pig, Plants, Egg etc. [9-11].
Detection of Vibrio scophthalmi in Turbot fish by LAMP assays described in this paper Provide a new diagnostic toolkit in support of effective control of Vibrio scophthalmi and all foodborne disease associated with Bacteria infections.

The results using a primer set designed by Primer Explorer V4 software and the optimized LAMP protocol demonstrated that the method effectively detected target sequences of $\mathrm{Vib}$ rio scophthalmi in Cultured turbot (Figure 1). Similar results reported a successfully Visual Detection of Pathogen in Fish by Using LAMP assay [12].

Due to the Simplicity of The LAMP reaction as it does not require expensive equipment. Several methods can be used to check for the LAMP reaction; the results of naked-eye assessments are shown in (Figure 1). Visual detection, become the easiest and simplest method to detect positive LAMP reactions by observing the turbidity, white precipitate of magnesium pyrophosphate formed as the results of the reaction between Pyrophosphate ions (byproducts of the LAMP reaction) with $\mathrm{Mg}^{2+}$ (Figure 1). The color of a positive reaction product of LAMP was green after the addition of casein dye, whereas the original pale-yellow color did not change if no reaction products were produced Visual detection of this precipitate or increase in the turbidity depends in the concentration of amplified DNA. It is difficult to visualize the turbidity at lower-target DNA concentrations $[13,14]$. This signifies its sensitivity, by amplifying a few copies of DNA to the extent of $10^{9}$ copies in less than $1 \mathrm{~h}[13,15]$. When mounted to the UVlight the amplified products appeared as a ladder-like pattern on the gel (Figure 1). Its advantage opened a wide range of the LAMP assay which has been successfully applied to the rapid diagnosis of some fish diseases [16-18].

In addition to its higher specificity, the LAMP assay for identification of Vibrio scophthalmi showed sufficient sensitivity, LAMP using a series of dilutions of $10^{-1}$ to $10^{-16}$ copies of DNA from the $16 \mathrm{~s}$ rDNA revealed a reproducible amplification whereby a Concentration of $1.25 \times 10^{-17} \mu \mathrm{g} / \mathrm{ml}$ was recorded in tube number 14 as the lowest Concentration to be amplified (Figure 2). The greater sensitivity of LAMP could be because of its high amplification efficiency and no time loss for thermal change under isothermal conditions [19]. Due to its higher Sensitivity and low false-negative rate makes LAMP Assay become betta er choice for the diagnosis of Vibrio scophthalmi in situations when lower concentrations of extracted DNA are expected [20].

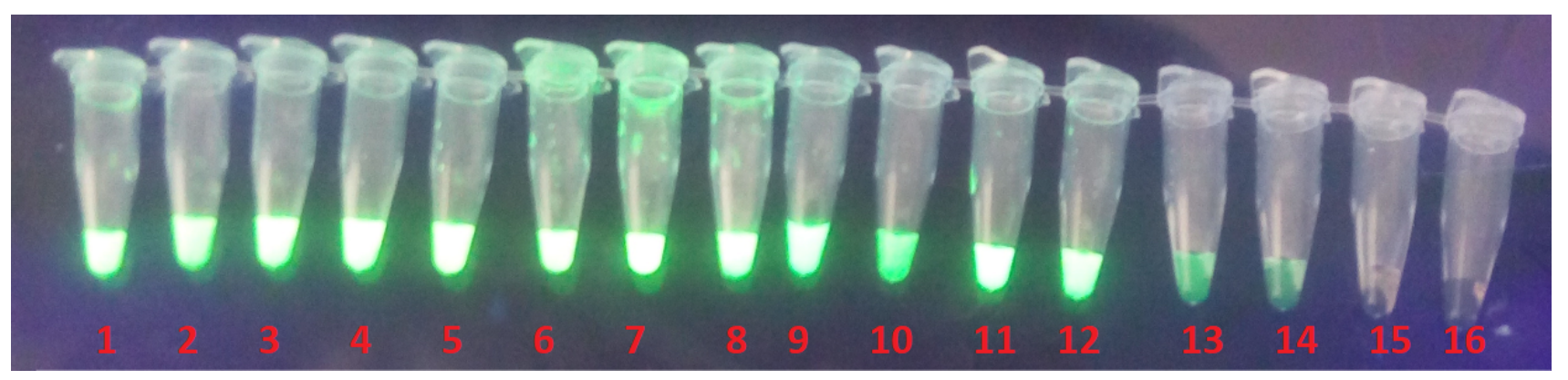

Figure 2: The LAMP products were visualized under UV light. No. 1-16 are serially diluted samples 10-1 to 10-16 respectively. Only Turbot Fish number 3 was used to test LAMP sensitivity. 
Citation: Choto P, Charles F, Gwekwe B, et al. (2020) Detection of Vibrio Pathogens from Cultured Turbot (Scophthalmus maximus) by LoopMediated Isothermal Amplification (LAMP). J Mar Biol Aquaculture Res 3(1):25-29

More interestingly, LAMP amplicons in the reaction tubes were visualized by naked eyes adding a calcein dye. LAMP-positive reactions appeared green, while the original pale-yellow color showed a negative reaction (Figure 2). This scenario highlights the advantage of using LAMP assay without the need for electrophoresis. Therefore, the use of Fluorescent dye could replace the gel electrophoresis in the LAMP assay.

Finally, the LAMP assay designated in this study represents a new sensitive, specific, and rapid protocol for the detection of Vibrio scophthalmi. This method provides an important diagnostic instrument for the detection of Vibrio scophthalmi infection in the laboratory. For further use in the field, more Experiment should be done into different fish species, from Cultured samples and Non-Cultured Sample.

\section{References}

1. Bostock J, McAndrew B, Richards R, et al. (2010) Aquaculture: Global status and trends. Philosophical Transactions of the Royal Society B: Biological Sciences 365: 2897-2912.

2. Siwa Msangi, Mimako Kobayashi, Miroslav Batka JL A (2015) Prospects for fisheries and aquaculture. AES.

3. Novriadi R (2016) Vibriosis in aquaculture. Omni-Akuatika 12.

4. Haenen OLM, Fouz B, Amaro C, et al. (2014) Vibriosis in aquaculture. $16^{\text {th }}$ EAFP Conference, Tampere, Finland, 4th September 2013. Bulletin of the European Association of Fish Pathologists 34: 138-148.

5. Cerdà-Cuéllar M, Rosselló-Mora R A, Lalucat J, et al. (1997) Vibrio scophthalmi sp. nov., A new species from turbot (Scophthalmus maximus). International Journal of Systematic Bacteriology 47: 58-61.

6. Fernández L, Álvarez B, Menéndez A, et al. (2008) Molecular tools for monitoring infectious diseases in aquaculture species. Dynamic Biochemistry, Process Biotechnology and Molecular Biology. Global Science Books 2: 33-43.

7. Notomi T, Mori Y, Tomita N, et al. (2015) Loop-mediated isothermal amplification (LAMP): Principle, features, and future prospects. Journal of Microbiology 53: 1-5.

8. Mitreva M (2017) The microbiome in infectious diseases. Infectious diseases. ( $4^{\text {th }}$ edn), Elsevier Ltd 1: 68-74.

9. Hu L, Ma L M, Zheng S, et al. (2018) Development of a novel loop-mediated isothermal amplification (LAMP) assay for the detection of Salmonella ser. Enteritidis from egg products. Food Control 88: 190-197.

10. Iwamoto T, Sonobe T, Hayashi K (2003) Loop-Mediated Isothermal Ampli cation for Direct Detection of. Society 41: 2616-2622.

11. Saetiew C, Limpaiboon T, Jearanaikoon P, et al. (2011) Rapid detection of the most common high-risk human papillomaviruses by loop-mediated isothermal amplification. Journal of Virological Methods 178: 22-30.

12. Hatem Soliman, Mona Saleh, Mansour El-Matbouli (2015) Detection of fish pathogens by loop-mediated isothermal. Veterinary Infection Biology 1247: 163-173.

13. Mori Y, Notomi T (2009) Loop-mediated isothermal amplification (LAMP): A rapid, accurate, and cost-effective diagnostic method for infectious diseases. Journal of Infection and Chemotherapy 15: 62-69.

14. Yamazaki W (2011) Sensitive and rapid detection of cholera toxin-producing Vibrio cholerae using loop-mediated isothermal amplification. Microbial Toxins 739: 13-22.

15. Mori Y, Nagamine K, Tomita N, et al. (2001) Detection of loop-mediated isothermal amplification reaction by turbidity derived from magnesium pyrophosphate formation. Biochemical and Biophysical Research Communications 289: 150-154.

16. Cai SH, Lu YS, Wu ZH, et al. (2010) Loop-mediated isothermal amplification method for rapid detection of Vibrio alginolyticus, the causative agent of vibriosis in mariculture fish. Letters in Applied Microbiology 50: 480-485.

17. Suebsing R, Oh MJ, Kim JH (2012) Development of a reverse transcription loop-mediated isothermal amplification assay for detecting nervous necrosis virus in olive flounder Paralichthys olivaceus. J Microbiol Biotechnol 22: 1021-1028.

18. Tsai MA, Wang PC, Yoshida T, et al. (2013) Development of a sensitive and specific LAMP PCR assay for detection of fish pathogen Lactococcus garvieae. Diseases of Aquatic Organisms 102: 225235.

19. Xia L, Zhang H, Lu Y, et al. (2015) Development of a loop-mediated isothermal amplification assay for rapid detection of nocardia salmonicida, the causative agent of nocardiosis in fish. J Microbiol Biotechnol 25: 321-327.

20. Kaneko H, Kawana T, Fukushima E, et al. (2007) Tolerance of loop-mediated isothermal amplification to a culture medium and biological substances. J Biochem Biophys Methods 70: 499501.

DOI: $10.36959 / 917 / 490$

Copyright: (C) 2020 Choto P, et al. This is an open-access article distributed under the terms of the Creative Commons Attribution License, which permits unrestricted use, distribution, and reproduction in any medium, provided the original author and source are credited. 